\title{
FRAKSI PEPTIDA ANTIOKSIDAN DARI KASEIN SUSU KAMBING
}

\author{
[Antioxidant peptide fraction from goat's milk casein]
}

\author{
Diana Lestari ${ }^{1{ }^{\star \star}}$, Joshua Evan1), dan Maggy Thenawidjaja Suhartono ${ }^{2)}$ \\ 1) Progam Studi Teknologi Pangan, Fakultas Teknobiologi, Universitas Katolik Indonesia Atma Jaya, Tangerang, Banten \\ 2) Departemen Ilmu dan Teknologi Pangan, Fakultas Teknologi Pertanian, IPB University, Bogor
}

Diterima 20 September 2019 / Disetujui 1 Desember 2020

\begin{abstract}
Milk bioactive peptides are derivative of milk protein produced either through enzymatic activity, digestive processes, or fermentation, that give functional properties. The study aimed to obtain bioactive peptides fraction derived from goat's milk casein through hydrolysis by papain, analyze the profiles of protein and peptides, and also test the antioxidative activity. The casein isolate was hydrolyzed by papain in a ratio of 100: $0.5(\mathrm{~V} / \mathrm{V})$ at $\mathrm{pH} 7.0$ and $50^{\circ} \mathrm{C}$. Analysis of protein concentration was carried out by the Bradford method and protein profile by SDS-PAGE. Antioxidant assay was carried out by the 2,2-diphenyl1-picrylhydrazyl (DPPH) method. A 1,000 ppm ascorbic acid solution was used as positive control. Peptide fractionation was done by membrane filtration with a cut off of $10 \mathrm{kD}$ and $30 \mathrm{kDa}$. The protein concentration of casein hydrolysates decreased significantly after hydrolysis process with papain. The electrophoresis results showed six protein bands in casein with molecular weight of 7-33 kDa. After the hydrolysis process, all hydrolysates only contained two protein bands with molecular weights of 8 and 5 $k D a$. The hydrolysis process increased the antioxidant activity of the casein. P0 and P2 hydrolysates had the highest antioxidant activity, and fractions with the highest antioxidant activity were fraction $<10 \mathrm{kDa}$ from P0 hydrolysate at $67.89 \%$ and $10-30 \mathrm{kDa}$ from $\mathrm{P} 2$ hydrolysate at $73.82 \%$. Molecular weight and hydrolysis time affected the antioxidant activity of the hydrolysates. Peptides below $30 \mathrm{kDa}$ have antioxidant activity, whereas those above $30 \mathrm{kDa}$ do not have any antioxidant activity. The antioxidant activity of the peptides decreases upon hydrolysis for more then 2 minutes.
\end{abstract}

Keywords: antioxidant, bioactive peptide, casein, fractionation, goat's milk

\begin{abstract}
ABSTRAK
Peptida bioaktif susu merupakan turunan protein susu yang dihasilkan baik melalui aktivitas enzimatik, proses pencernaan, maupun fermentasi sehingga memberikan sifat fungsional. Tujuan dari studi ini adalah untuk memperoleh peptida bioaktif yang berasal dari kasein susu kambing menggunakan papain, menganalisis profil protein dan peptida yang diperoleh serta menguji aktivitas antioksidan. Isolat kasein dihidrolisis dengan papain dengan perbandingan 100:0,5 (v/v) pada $\mathrm{pH} 7,0$ dan suhu $50^{\circ} \mathrm{C}$. Analisis konsentrasi protein dilakukan dengan metode Bradford dan profil protein dengan SDS-PAGE. Evaluasi aktivitas antioksidan dilakukan dengan uji 2,2-diphenyl-1-picrylhydrazyl (DPPH).Asam askorbat dengan konsentrasi 1.000 ppm digunakan sebagai kontrol positif. Fraksinasi peptida dilakukan dengan filtrasi membran dengan cut off $10 \mathrm{kD}$ dan $30 \mathrm{kDa}$. Konsentrasi protein dari hidrolisat kasein menurun secara signifikan setelah dihidrolisis dengan papain. Profil elektroforesis kasein menunjukkan enam pita dengan berat molekul 7-33 kDa. Setelah proses hidrolisis, hanya diperoleh dua pita dengan berat molekul sekitar 8 dan $5 \mathrm{kDa}$ pada semua hidrolisat. Proses hidrolisis dapat meningkatkan sifat antioksidatif dari kasein. Hidrolisat P0 dan P2 mempunyai aktivitas antioksidan yang tertinggi, dengan fraksi yang memiliki aktivitas antioksidan tertinggi adalah fraksi $<10 \mathrm{kDa}$ pada hidrolisat P0 sebesar 67,89\% dan fraksi 10-30 kDa pada hidrolisat P2 sebesar $73,82 \%$. Berat molekul dan waktu hidrolisis diketahui memengaruhi aktivitas antioksidan. Peptida dengan berat molekul dibawah $30 \mathrm{kDa}$ diketahui memiliki aktivitas antioksidan, sedangkan peptida $>30 \mathrm{kDa}$ tidak memiliki aktivitas antioksidan. Aktivitas antioksidan menurun pada perlakuan waktu hidrolisis lebih dari 2 menit.
\end{abstract}

Kata kunci: antioksidan, fraksinasi, kasein, peptida bioaktif, susu kambing

*Penulis Korespondensi:

E-mail: diana.lestari@atmajaya.ac.id 


\section{PENDAHULUAN}

Susu merupakan salah satu minuman yang populer untuk dikonsumsi, salah satu yang paling umum adalah susu sapi. Susu lainnya yang tidak kalah bernutrisi jika dibandingkan susu sapi adalah susu kambing. Susu kambing cukup populer terutama bagi seseorang yang mengidap alergi terhadap protein susu sapi. $\beta$-lactoglobulin merupakan komponen utama dalam whey susu sapi yang berperan sebagai alergen dalam susu sapi, yang tidak ditemui dalam air susu ibu (ASI). Bayi-bayi yang menderita alergi pada susu sapi dilaporkan dapat ditangani dengan pemberian susu kambing (Park, 1994). Susu kambing juga mengandung $\alpha_{s 1}-k a s e i n$ yang rendah, yaitu molekul protein yang sulit dicerna dan dapat menyebabkan masalah pencernaan pada bayi (Yangilar, 2013). Selain itu susu kambing diketahui mengandung A2 $\beta$-kasein yang bersifat hyppoallergenic (Jung et al., 2017).

Protein merupakan makromolekul yang terdiri atas asam amino yang dihubungkan dengan ikatan peptida. Selain mempunyai fungsi sebagai pembentuk jaringan, fragmen protein mempunyai berbagai fungsi biologis terhadap kesehatan atau yang lebih dikenal sebagai peptida bioaktif. Antibakteri, antihipertensi, antikolesterol, dan antioksidan merupakan beberapa fungsi bioaktif dari fragmen protein (Padaga dan Aulanni'am, 2017).

Peptida bioaktif susu dapat diperoleh dengan beberapa cara yaitu dengan melakukan fermentasi, hidrolisis dengan enzim pencernaan (in vivo), dan hidrolisis oleh enzim proteolitik (in vitro) (Mohanty et al., 2016). Salah satu enzim protease dari tanaman dan sudah umum digunakan adalah papain. Papain merupakan kelompok sistein protease yang bersumber dari tanaman pepaya yang dapat menghidrolisis protein dalam spektrum yang luas (Rawlings dan Salvesen, 2013).

Salah satu manfaat dari peptida bioaktif adalah sebagai antioksidan, yaitu senyawa yang mampu menangkal radikal bebas. Antioksidan dapat mendonorkan satu elektronnya kepada senyawa radikal bebas sehingga dampak negatif dari radikal bebas dapat dihambat. Radikal bebas pada tubuh dapat merusak sel-sel tubuh jika dibiarkan menumpuk secara terus menerus, hal ini dapat disebabkan radikal bebas bersifat tidak stabil dan dapat mengambil elektron dari molekul lain. Sebenarnya tubuh mempunyai kemampuan untuk menetralisir radikal bebas, namun jumlah dihasilkannya antioksidan tersebut terbatas (Syukur et al., 2011). Sehingga dibutuhkan peran antioksidan dari luar untuk menetralkan radikal bebas tersebut (Kusumaningtyas et al., 2015a; Padaga dan Aulanni'am, 2017).

Aktivitas antioksidan peptida susu kambing ditemukan dengan menghidrolisis susu kambing dengan protease Lactobacillus plantarum S31 pada fraksi 11 dengan $\mathrm{pH}$ 5,0 sebesar 29\%. Fraksi ini juga memiliki aktivitas penghambatan pertumbuhan bakteri Entero Pathogenic Escherichia coli (EPEC K1.1), Staphylococcus aureus, dan Listeria monocytogenes (Herlina et al., 2019).

Kandungan protein susu kambing secara umum adalah 3,4\% angka tersebut sedikit lebih tinggi dari susu sapi yang hanya $3,2 \%$ dan lebih rendah dari protein susu domba $(6,2 \%)$ (Yangilar, 2013). Kambing peranakan etawa merupakan salah satu jenis kambing yang diternakkan di Indonesia. Susu kambing peranakan etawa diketahui memiliki kandungan protein yang tinggi yaitu sebesar $3,8-3,9 \%$. Nilai tersebut dipengaruhi oleh jenis pakan yang diberikan (Ratya et al., 2017). Protein dalam susu terdiri dari kasein dan whey dengan perbandingan 80:20 (Selvaggi et al., 2014). Sehingga berpotensi untuk menghasilkan peptida yang bersifat bioaktif dari kasein susu kambing yang diternakkan di Indonesia. Data mengenai aktivitas antioksidan kasein susu kambing lokal belum banyak diteliti terutama menggunakan enzim papain. Tujuan dari penelitian ini adalah untuk memperoleh peptida bioaktif dari kasein susu kambing menggunakan enzim papain, menganalisis profil protein dan peptida yang diperoleh serta mengujinya sebagai antioksidan.

\section{BAHAN DAN METODE}

\section{Bahan}

Bahan yang digunakan dalam penelitian ini adalah susu kambing peranakan etawa yang berasal dari peternak di Bogor, enzim papain (Merck, USA), membran filtrasi $10 \mathrm{kDa}$ (Amicon $\AA$, Irlandia), membran filtrasi $30 \mathrm{kDa}$ (Sartorius, Inggris), LMW (Unstained Low Range Protein Ladder) marker (PageRuler ${ }^{\mathrm{TM}}$, Thermo Scientific, USA) dan 2,2diphenyl-1-picrylhydrazyl (DPPH) (Hi-Media, India).

\section{Preparasi dan isolasi kasein susu kambing (Bezerra et al., 2013)}

Sebanyak $1 \mathrm{~L}$ susu kambing segar dibuang lemaknya dengan cara disentrifugasi $2.000 \mathrm{~g}$ pada suhu $4^{\circ} \mathrm{C}$ selama 30 menit. Kemudian susu dipasteurisasi pada suhu $72^{\circ} \mathrm{C}$ selama 15 detik. Susu didinginkan hingga $40^{\circ} \mathrm{C}$, lalu ditambahkan $\mathrm{HCl}$ (Merck, Jerman) $2 \mathrm{~N}$ hingga $\mathrm{pH}$ susu menjadi 4,6 yang merupakan titik isoelektrik susu. Susu kemudian disentrifugasi dengan kecepatan $7.100 \mathrm{~g}$ selama 30 menit. Supernatan yang berisi whey dan $\mathrm{HCl}$ kemudian dipisahkan sehingga diperoleh kasein pada endapan. Endapan kasein yang diperoleh dilakukan pembilasan dengan menambahkan akuades $200 \mathrm{~mL}$ sebanyak tiga kali. Kasein kemudian disimpan pada suhu $20^{\circ} \mathrm{C}$ (Bezerra et al., 2013). Proses isolasi kasein ini dilakukan satu kali untuk 
selanjutnya digunakan untuk dua kali ulangan perlakuan pada masing-masing uji.

\section{Hidrolisis kasein susu kambing (Chalabi et al., 2014)}

Kasein dilarutkan didalam bufer fosfat $0,05 \mathrm{M}$ $\mathrm{pH} 7,0$ dengan konsentrasi $15 \% \mathrm{~b} / \mathrm{v}$. Hidrolisis dimulai dengan melakupan preparasi larutan enzim yaitu melarutkan bubuk papain murni (Merck, Jerman, $30.000 \mathrm{USP}-\mathrm{U} / \mathrm{mg}$ ) dalam bufer fosfat dengan perbandingan 1:10 (b/v). Kemudian proses hidrolisis dilakukan dengan perbandingan larutan kasein dan enzim 100:0,5 (v/v) pada $\mathrm{pH} 7,0$ dan suhu $50^{\circ} \mathrm{C}$ dengan variasi waktu $0,1,2$, dan 3 menit. Proses hidrolisis dihentikan dengan pemanasan pada suhu $80^{\circ} \mathrm{C}$ selama 15 menit. Hidrolisat kemudian disentrifugasi dengan kecepatan $2.000 \mathrm{~g}$ selama 5 menit pada suhu $4^{\circ} \mathrm{C}$ untuk mengendapkan protein besar. Kemudian hidrolisat berupa supernatan disimpan pada suhu $-20^{\circ} \mathrm{C}$ untuk dianalisis lebih lanjut (Chalabi et al., 2014).

\section{Pengukuran kadar protein hasil hidrolisis (He, 2011)}

Uji kadar protein dilakukan dengan metode Bradford, dengan kurva standar menggunakan Bovine Serum Albumin. Sebanyak 0,4 mL hidrolisat dimasukkan ke dalam tabung reaksi dan ditambahkan dengan $8 \mathrm{~mL}$ reagen Bradford. Kemudian larutan dihomogenisasi dan diinkubasi pada suhu ruang selama 5 menit. Absorbansi diukur pada panjang gelombang $595 \mathrm{~nm}(\mathrm{He}, 2011)$.

\section{Fraksinasi peptida dengan filtrasi membran (Kusumaningtyas et al., 2015b)}

Fraksinasi peptida dilakukan dengan cara sentrifugasi menggunakan membran filtrasi. Hirolisat hasil hidrolisis difraksinasi dengan menggunakan membran cut off $10 \mathrm{kD}$ (Amicon $\AA$ ) dan $30 \mathrm{kDa}$ (Satorius) dengan kecepatan $4.000 \mathrm{~g}$ selama $20 \mathrm{me}-$ nit. Kemudian diperoleh 3 fraksi yaitu peptida yang berukuran $<10 \mathrm{kDA}, 10-30 \mathrm{kDa}$, dan $>30 \mathrm{kDA}$.

\section{Analisis profil peptida dengan SDS-PAGE (Singh et al., 2011) \\ Analisis ini dilakukan berdasarkan Singh et al.} (2011) baik pada sampel sebelum dan sesudah fraksinasi. Sampel dilarutkan di dalam larutan SDS $5 \%$ dengan perbandingan 1:5, lalu campuran dipanaskan pada suhu $85^{\circ} \mathrm{C}$ selama 1 jam pada waterbath shaker (GFL 1086, Jerman). Campuran kemudian disentrifugasi dengan kecepatan $2.000 \mathrm{~g}$ selama 5 menit pada suhu ruang, kemudian supernatan dipisahkan. Supernatan yang diperoleh dicampurkan dengan bufer $((6 \%$ Tris- $\mathrm{HCl}$ (Merck German) $1 \mathrm{M} \mathrm{pH} 6,8 ; 50 \%$ gliserol (Merck, Jerman) $50 \%$; 20\% SDS (Merck, Jerman) $10 \% ; 5 \% \beta-$ merkaptoetanol (Merck, Jerman); 10\% bromophenol blue (Sigma, Jerman) 1\%; 9\% akuades)) dengan perbandingan 1:1. Campuran kemudian dipanaskan di dalam air mendidih selama 2 menit. Sebanyak 6 $\mu \mathrm{L}$ kasein, $4 \mu \mathrm{L}$ marker LMW dan $8 \mu \mathrm{L}$ peptida dimasukan ke dalam sumur gel. Konsentrasi gel SDSPAGE yang digunakan untuk gel pemisah adalah $18 \%$ ((akrilamid (Merck, Jerman); bis-akrilamid (Amresco, US); Tris $\mathrm{HCl}$ pH 8,8; ammonium persulfat (Merck Jerman); TEMED (Merck, Jerman); dan SDS (Merck, German) 10\%)) dan gel penahan adalah 6\% (akrilamid; bis-akrilamid; tris $\mathrm{HCl} \mathrm{pH} \mathrm{6,8;}$ amonium persulfat; TEMED dan SDS 10\%). Marker LMW digunakan sebagai standar protein. Proses elektroforesis dilakukan selama 3 jam dengan tegangan $70 \mathrm{~V}$ dan $5 \mathrm{~mA}$ hingga pewarna (bromophenol blue) bergerak hampir mencapai bagian bawah gel. Gel divisualisasi dengan larutan pewarna $((0,1 \%$ Coomasie Brilliant Blue R-250 (Merck, Jerman); 45\% metanol (Merck Jerman); 44,9\% akuades; $10 \%$ asam asetat glasial (Merck, Jerman)) dan pewarna dilunturkan dengan larutan peluntur (10\% metanol; $10 \%$ asam asetat glasial; $80 \%$ akuades).

\section{Uji aktivitas antioksidan (Kusumaningtyas et al., 2015b)}

Uji ini dilakukan baik pada sampel sebelum dan sesudah fraksinasi. 2,2-diphenyl-1-picrylhydrazyl (DPPH) dilarutkan didalam etanol 96\% (Merck, Jerman) dengan konsentrasi 0,1 mM. Kemudian sebanyak $100 \mu \mathrm{L}$ hidrolisat peptida dicampurkan dengan $100 \mu \mathrm{L}$ larutan DPPH. Etanol 96\% ditambah dengan larutan DPPH digunakan sebagai blanko. Kontrol positif yang digunakan berupa asam askorbat 1.000 ppm (Sigma, Jerman) ditambah dengan larutan DPPH. Campuran diinkubasi pada suhu ruang dengan kondisi gelap selama 30 menit. Setelah 30 menit, nilai absorbansi diukur dengan microplate reader (Tecan Austria $\mathrm{GmbH}$ Model Infinite $200 \mathrm{PRO}$ ). pada panjang gelombang $517 \mathrm{~nm}$ (Kusumaningtyas et al., 2015b). Perhitungan aktivitas antioksidan dinyatakan dengan persen penangkapan radikal bebas (\% Radical Scavenging Activity) dengan rumus (Kusumaningtyas et al., 2015b):

\section{Aktivitas Antioksidan (\% RSA $)=$}

$\left(\frac{\text { absorbansi blanko- absorbansi sampel }}{\text { absorbansi blanko }}\right) \times 100 \ldots$

Absorbansi blanko adalah absorbansi etanol teknis yang dicampurkan dengan larutan DPPH 0,1 $\mathrm{mM}$. Absorbansi sampel adalah absorbansi hidrolisat peptida atau asam askorbat 1.000 ppm dicampurkan dengan larutan DPPH 0,1 mM. 


\section{Pengolahan dan analisis data}

Analisis data dalam penelitian ini dilakukan dengan analisis statisik dengan aplikasi IBM SPSS Statistic 24. Hasil dari analisis konsentrasi protein dan aktivitas antioksidan dilakukan dengan dua kali pengulangan perlakuan, data yang diperoleh kemudian dianalisis dengan uji ANOVA satu arah dengan uji lanjut Duncan.

\section{HASIL DAN PEMBAHASAN}

\section{Konsentrasi protein setelah hidrolisis}

Substrat kasein susu kambing dihidrolisis dengan enzim papain. Hidrolisat PO merupakan hidrolisat yang dihidrolisis selama 0 menit, P1 selama 1 menit, hidrolisat P2 selama 2 menit dan P3 selama 3 menit. Tabel 1 menunjukkan bahwa semua hidrolisat memiliki konsentrasi protein yang tidak berbeda nyata jika dibandingkan antar hidrolisat $(P>0,05)$. Jika dibandingkan dengan kasein, kasein memiliki konsentrasi protein yang lebih tinggi dari semua hidrolisat secara nyata $(P<0,05)$. Perbedaan yang tidak signifikan antar hidrolisat mungkin disebabkan oleh konsentrasi enzim papain yang digunakan sudah mampu menghidrolisis kasein sejak menit pertama, sehingga pertambahan waktu inkubasi sudah tidak lagi mengurangi konsentrasi protein secara nyata.

Tabel 1. Konsentrasi protein setiap hidrolisat

\begin{tabular}{cc}
\hline Jenis Hidrolisat & Konsentrasi Protein $(\mathrm{mg} / \mathrm{mL})$ \\
\hline P0 & $1,05 \pm 0,21^{\mathrm{a}}$ \\
P1 & $1,12 \pm 0,11^{\mathrm{a}}$ \\
P2 & $1,06 \pm 0,02^{\mathrm{a}}$ \\
P3 & $1,10 \pm 0,14^{\mathrm{a}}$ \\
Kasein & $2,27 \pm 0,19^{\mathrm{b}}$ \\
\hline
\end{tabular}

Hidrolisis kasein dengan papain yang dilaporkan oleh Lestari dan Soesilo (2017) selama tiga menit juga menunjukkan penurunan konsentrasi protein sampai dengan $50 \%$. Penurunan konsentrasi protein pada hidrolisat dapat disebabkan oleh waktu inkubasi enzim yang digunakan cukup untuk menghidrolisis kasein dan menghasilkan fragmenfragmen peptida yang lebih kecil. Metode Bradford yang digunakan pada penelitian ini merupakan metode pengukuran konsentrasi protein total, pada metode ini coomasie brilliant blue (CBB) akan berikatan dengan protein dengan residu asam amino dengan rantai samping triptofan, tirosin, fenilalanin, arginin, histidin dan leusin pada sampel pada suasana asam dan menghasilkan warna biru (Purwanto, 2014; Utami et al., 2016). Metode Bradford digunakan karena kemurnian reagen yang tinggi, reaksinya yang cepat dan sensitifitasnya yang tinggi. Pada proses hidrolisis, protein dipecah oleh enzim menjadi peptida maupun asam amino. Peptida maupun asam amino tidak dapat membentuk kompleks dengan CBB sehingga tidak menghasilkan warna biru (Utami et al., 2016), yang mengakibatkan penurunan nilai absorbansi ketika diukur pada panjang gelombang $595 \mathrm{~nm}$. Hal tersebut menyebabkan diperoleh penurunan konsentrasi protein pada hidrolisat jika dibandingkan dengan kasein yang tidak dihidrolisis. Selain mengetahui konsentrasi protein, uji ini dapat berguna untuk mengetahui keberhasilan proses hidrolisis.

\section{Profil peptida dengan elektroforesis SDS-PAGE sebelum proses fraksinasi}

Berdasarkan hasil elektroforesis SDS-PAGE, terdapat enam pita protein pada kasein dengan berat molekul sebesar 33; 29; 22; 14; 18 dan $7 \mathrm{kDa}$. Semua hidrolisat (P0, P1, P2, dan P3) menunjukkan protein-protein besar pada kasein sudah terdegradasi dan menghasilkan 2 pita dengan berat molekul kecil pada bagian bawah yaitu 8 dan $5 \mathrm{kDa}$. Meskipun pada hidrolisat PO reaksi enzim langsung dihentikan setelah substrat dan enzim bertemu, namun dari hasil SDS-PAGE menunjukkan reaksi enzim sudah berjalan (Gambar 1). Hal ini mungkin disebabkan reaksi enzim yang berjalan cepat pada $\mathrm{pH}$ dan suhu optimum enzim papain yaitu $\mathrm{pH} 7,0$ dan suhu $50^{\circ} \mathrm{C}$ (Kusumadjaja dan Dewi, 2010). Selain itu proses pemanasan yang dilakukan untuk menghentikan reaksi enzim juga dapat mendenaturasi protein kasein sehingga dapat memengaruhi konsentrasi protein dan profil SDS-PAGE protein.

Gambar 1 menunjukkan bahwa pada sampel kasein $(K)$ terdapat total enam pita protein dengan tiga pita utama dan tiga pita tambahan. Ketiga pita utama tersebut dapat terlihat secara jelas dan mempunyai berat molekul sekitar 33, 29, dan 22 $\mathrm{kDa}$. Tiga pita tersebut merupakan $\alpha$-kasein, $\beta$ kasein, dan $\mathrm{k}$-kasein secara berurutan (Wang et al., 2013; Costa et al., 2014). Terdapat tiga pita lainnya pada kasein dengan berat molekul 14, 18, dan 7 $\mathrm{kDa}$ dengan intensitas yang lebih rendah jika dibandingkan dengan tiga pita sebelumnya. Ketiga pita tersebut dapat berupa protein tambahan yang terbentuk saat proses pemisahan kasein dengan whey maupun saat proses pasteurisasi. Panas dapat mendenaturasi protein, sehingga dapat memutus ikatan hidrogen pada protein sehingga struktur akan berubah, namun panas tidak dapat merusak struktur primer protein (Matsuura et al., 2015). Oleh karena itu memungkinkan diperoleh pita dengan berat molekul yang lebih kecil dari berat molekul kasein.

Pada semua sampel hidrolisat, diperoleh 2 pita pada pada bagian bawah gel dengan berat molekul 8 dan $5 \mathrm{kDa}$. Sehingga dapat diketahui bahwa proses hidrolisis menghasilkan peptida dengan ukuran kecil. 


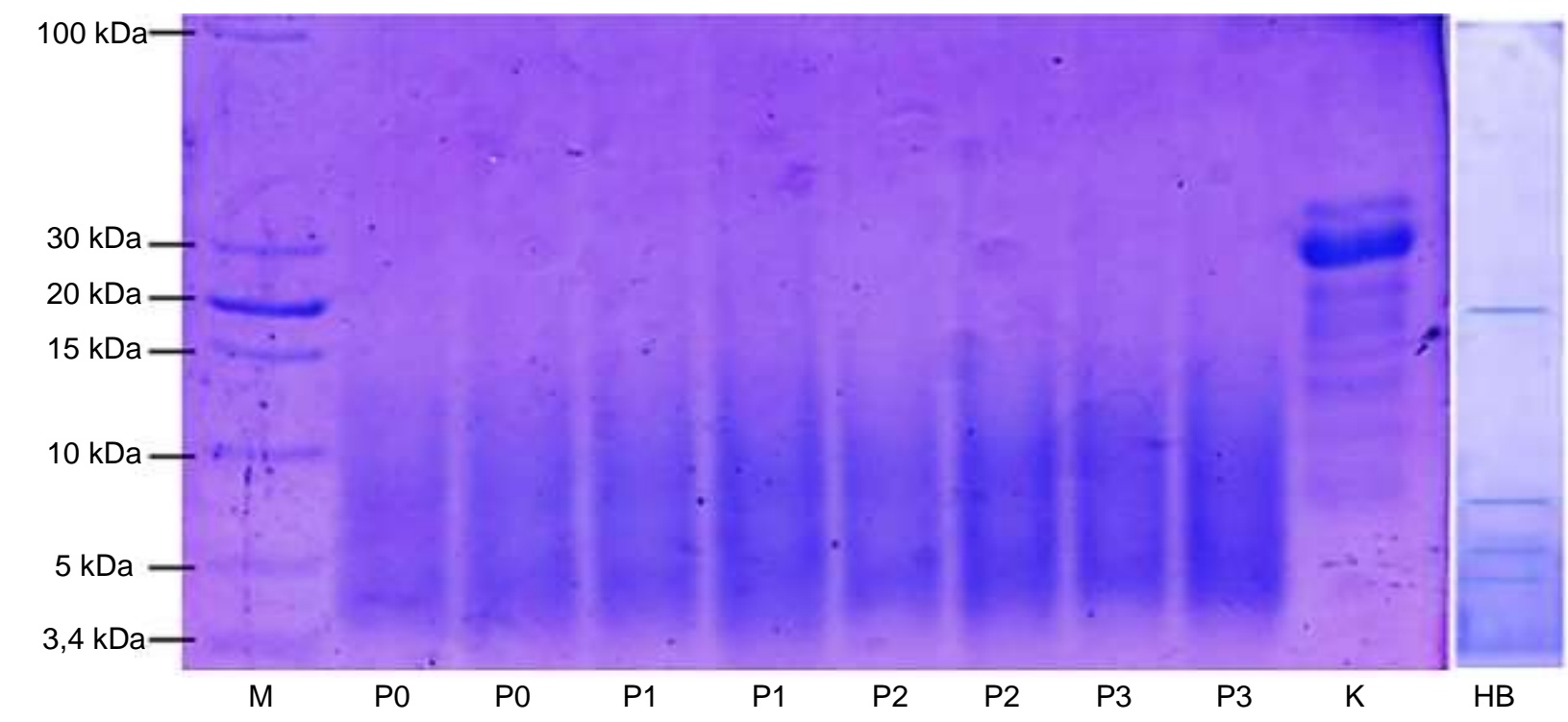

Keterangan: $\mathrm{M}=$ Marker; $\mathrm{P} 0=$ Hidrolisat 0 menit; $\mathrm{P} 1=$ Hidrolisat 1 menit; $\mathrm{P} 2=$ Hidrolisat 2 menit; $\mathrm{P} 3=$ Hidrolisat 3 menit; $\mathrm{K}=$ Kasein; $\mathrm{HB}=$ Hidrolisat susu kambing oleh bromelin (Kusumaningtyas et al., 2015b)

\section{Gambar 1. Hasil elektroforesis SDS-PAGE kasein dan hidrolisat kasein sebelum proses fraksinasi}

Hal ini sesuai dengan penelitian yang dilakukan Chalabi et al. (2014), hasil hidrolisis kasein dengan papain akan menghasilkan hidrolisat dengan ukuran dibawah $14 \mathrm{kDa}$. Selain itu hasil ini menunjukkan keberhasilan dari proses hidrolisis oleh enzim papain, kasein yang berukuran sekitar 19-32 kDa terhidrolisis menjadi peptida dengan ukuran lebih kecil. Papain dapat menghidrolisis secara sempurna protein yang berukuran 66-88 kDa (Lestari dan Soesilo, 2017). Selain itu proses hidrolisis yang dilakukan pada kondisi optimum papain yaitu $\mathrm{pH} 7,0$ dan suhu $50^{\circ} \mathrm{C}$, menyebabkan proses hidrolisis terjadi secara cepat dan optimum sehingga menghasilkan peptida dengan berat molekul yang sama pada semua perlakuan waktu hidrolisis yang diberikan. Hal ini menandakan proses hidrolisis telah selesai. Hidrolisis susu kambing segar menggunakan enzim bromelin selama 60 menit juga menghasilkan peptida dengan ukuran 12-35 kDa (Kusumaningtyas et al., 2015b) (Gambar 1).

\section{Aktivitas antioksidan sebelum proses fraksinasi}

Gambar 2 menunjukkan bahwa kasein (sebelum proses hidrolisis) tidak memiliki aktivitas antioksidan sedangkan semua hidrolisat hasil hidrolisis kesein menggunakan enzim papain memiliki aktivitas antioksidan. Hal ini menunjukkan bahwa proses hidrolisis dapat mengaktifkan atau membuat sifat antioksidan dari protein yang sebelumnya tidak ada menjadi muncul. Hidrolisat P0 dan P2 memiliki aktivitas antioksidan tertinggi masing-masing dengan nilai \% RSA sebesar 63,4 dan 63,2\%. Nilai tersebut tidak berbeda nyata dengan kontrol positif (asam askorbat 1.000 ppm). Hidrolisat P1 memiliki aktivitas antioksidan dengan nilai \% RSA sebesar 42,0\% lebih rendah dari P0 dan P2, namun dengan perbedaan yang tidak signifikan $(P>0,05)$. Aktivitas antioksidan hidrolisat P3 sebesar 23,3\%, merupakan aktivitas antioksidan terendah diantara seluruh hidrolisat. Hal ini menandakan bahwa waktu hidrolisis yang lebih panjang cenderung merusak aktivitas antioksidan yang sudah terbentuk.

Hasil tersebut dapat disebabkan karena faktor utama yang memengaruhi aktivitas antioksidan peptida adalah komposisi dan susunan asam aminonya, yaitu peptida mempunyai sekuens asam amino yang banyak mengandung asam amino hidrofobik, aromatik dan yang mempunyai gugus sulfur. Asam amino yang bersifat hidrofobik antara lain adalah glisin, alanin, valin, leusin dan prolin. Asam amino yang memiliki gugus sulfur antara lain adalah sistein dan metionin. Asam amino aromatik antara lain adalah fenilalanin, tirosin dan triptofan. Asam amino hidrofobik dan aromatik mempunyai cincin imidazole yang dapat berguna sebagai transfer elektron terhadap radikal bebas. Selain itu pada asam amino triptofan dan proline terdapat cincin pyrrolidine dan indol yang dapat mendonorkan hidrogen terhadap radikal bebas (Zou et al., 2016). Hal ini yang dapat memengaruhi aktivitas antioksidan dari peptida. Proses hidrolisis memengaruhi aktivitas antioksidan, proses hidrolisis dapat memunculkan maupun menghilangkan aktivitas antioksidan dari suatu peptida (Costa et al., 2012). Pada penelitian ini, proses hidrolisis memunculkan aktivitas antioksidan dari kasein. 


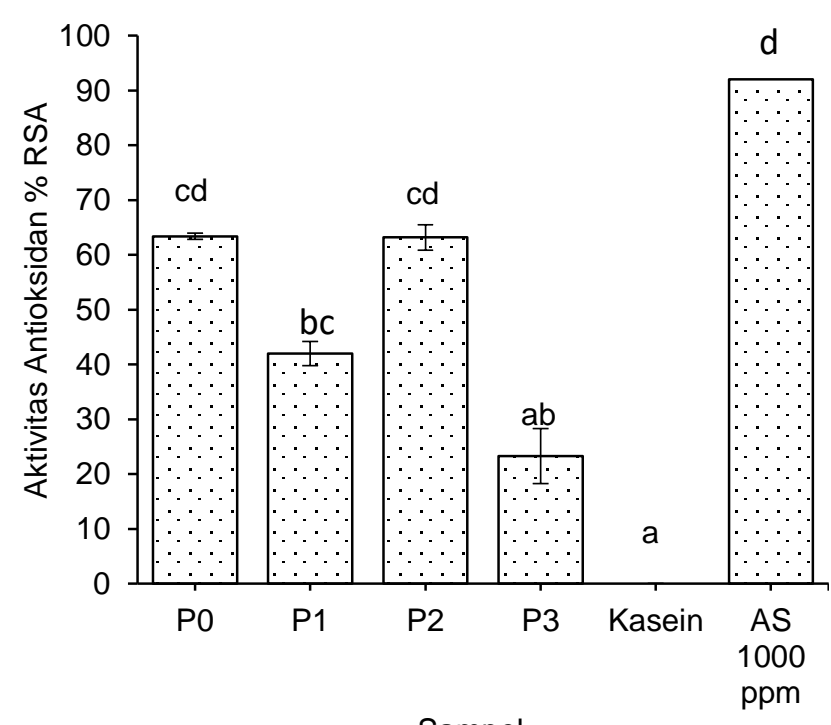

Sampel

Keterangan: $\mathrm{P} 0=$ Hidrolisat 0 menit; $\mathrm{P} 1=$ Hidrolisat 1 menit; P2= Hidrolisat 2 menit; $\mathrm{P} 3=$ Hidrolisat 3 menit; AS 1.000 ppm= kontrol positif asam askorbat

Gambar 2. Aktivitas antioksidan (dinyatakan dengan \% RSA terhadap DPPH) kasein dan hidrolisat kasein sebelum proses fraksinasi

Perbedaan lama waktu hidrolisis memengaruhi aktivitas antioksidan secara nyata. Hidrolisis kasein lebih dari dua menit dapat menurunkan aktivitas antioksidan. Hal ini dapat dikarenakan semakin lama waktu hidrolisis maka proses pemecahan protein yang terjadi semakin banyak, sehingga memungkinkan peptida yang telah terbentuk dan mempunyai aktivitas antioksidan menjadi terdegradasi kembali. Selain waktu hidrolisis, jenis protease yang digunakan, jenis substrat, dan suhu hidrolisis juga turut memengaruhi jenis peptida yang terbentuk, sehingga dapat berpengaruh terhadap aktivitas antioksidan yang dihasilkan. Herlina et al. (2019) melaporkan aktivitas antioksidan ditemui pada hidrolisat susu kambing yang dihidrolisis oleh protease fraksi 11 Lactobacillus plantarum S31 dengan suhu $37^{\circ} \mathrm{C}$ selama 18 jam sebesar 29,3 $\pm 0,005$ (susu kambing $\mathrm{pH}$ 5,0 ) dan $24,08 \% \pm 0,027$ (susu kambing $\mathrm{pH} 7,0$ ).

\section{Profil peptida dengan elektroforesis SDS-PAGE setelah proses fraksinasi}

Hidrolisat P0 dan P2 yang mempunyai aktivitas antioksidan tertinggi dilanjutkan dengan proses fraksinasi. Hasil SDS-PAGE pertama (Gambar 1), telah menunjukkan bahwa hidrolisat kasein susu kambing yang dihidrolisis oleh enzim papain hanya menunjukkan pita protein dengan berat molekul kecil, sehingga proses fraksinasi ini lebih mengarah kepada pemekatkan protein dengan berat molekul kecil yang diduga memiliki aktivitas antioksidan yang tinggi. Gambar 3 menunjukkan terdapat pita yang tebal pada fraksi $<10 \mathrm{kDa}$ baik pada hidrolisat P0 dan P2 yang menunjukkan protein dengan berat molekul kecil telah terpisah dan terkonsentrasi.

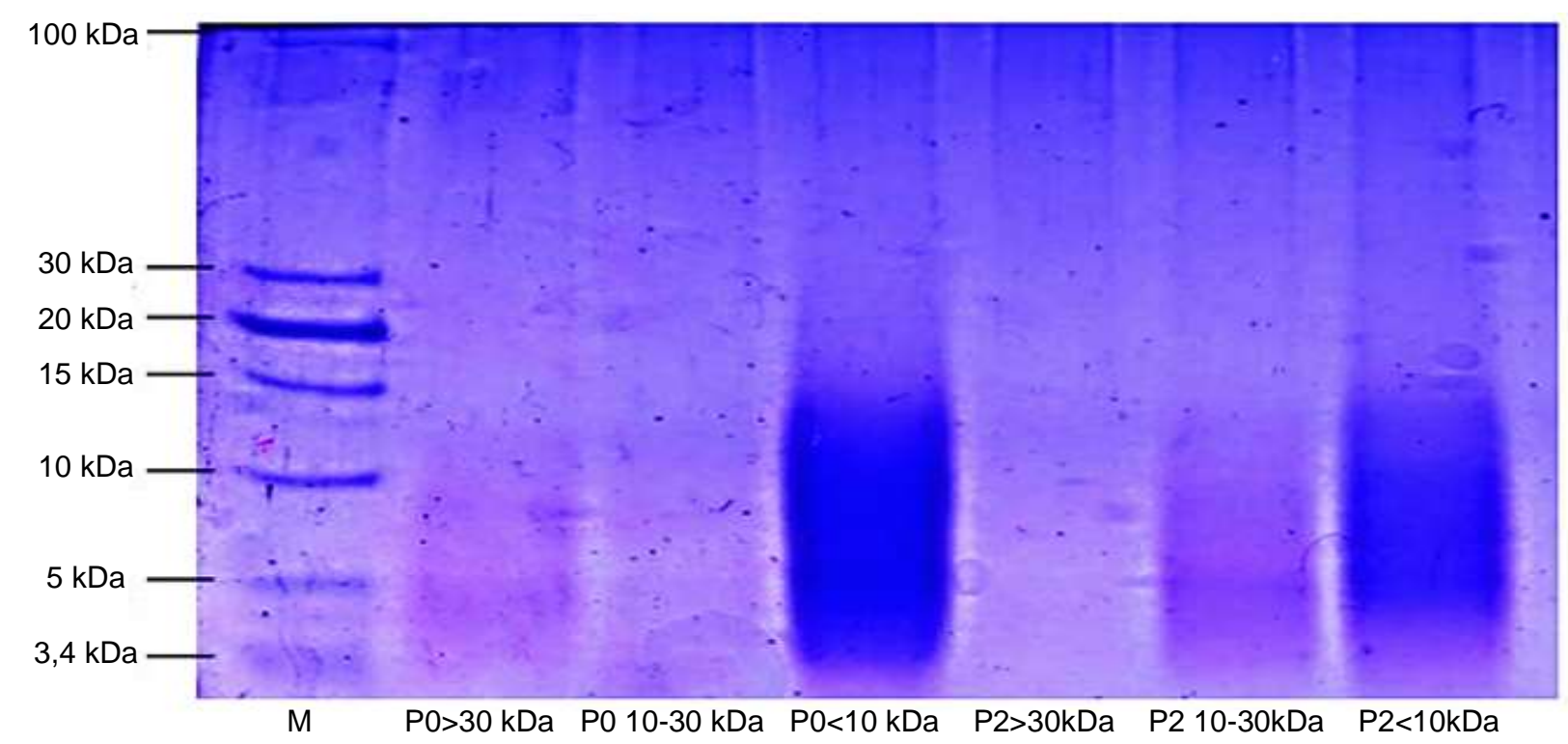

Ketarangan: $\mathrm{P} 0>30 \mathrm{kDa}=$ Fraksi Hidrolisat 0 menit dengan $\mathrm{BM}>30 \mathrm{kDa} ; \mathrm{P} 0$ 10-30 kDa $=$ Fraksi Hidrolisat 0 menit dengan $\mathrm{BM} 10-30 \mathrm{kDa}$; $\mathrm{P} 0<10 \mathrm{kDa}=$ Fraksi Hidrolisat 0 menit dengan $\mathrm{BM}<10 \mathrm{kDa}$; $\mathrm{P} 2>30 \mathrm{kDa}=$ Fraksi Hidrolisat 2 menit dengan $\mathrm{BM}>30 \mathrm{kDa}$; P2 10-30 kDa= Fraksi Hidrolisat 2 menit dengan BM 10-30kDa; P2 $<10 \mathrm{kDa}=\mathrm{Fraksi}$ Hidrolisat 2 menit dengan $\mathrm{BM}<10 \mathrm{kDa}$

Gambar 3. Hasil elektroforesis SDS-PAGE hidrolisat P0 dan P2 setelah proses fraksinasi 
Pita tersebut adalah dengan ukuran 9 dan 5 $\mathrm{kDa}$. Pita protein pada fraksi $10-30 \mathrm{kDa}$ terutama hidrolisat P2 ditemukan pita dengan intensitas yang rendah dengan ukuran 16 dan $5 \mathrm{kDa}$, yang menunjukkan hidrolisat P0 dan P2 tidak banyak mengandung protein dengan berat molekul sedang dan tidak semua protein kecil melewati membran filter. Hal ini juga dapat terjadi karena membran filtrasi yang digunakan sudah penuh dengan kerak tapis (substansi dengan berat molekul lebih besar yang menyumbat membran). Kerak tapis yang memenuhi membran dapat membuat peptida yang seharusnya dapat melewati membran, menjadi tertahan pada membran (Janson, 2012).

Hidrolisat P0 fraksi $>30 \mathrm{kDa}$ juga diketahui memiliki pita dengan intensitas rendah yang mempunyai ukuran $9 \mathrm{kDa}$. Sama seperti penjelasan sebelumnya, hal tersebut terjadi karena penumpukan pada kerak tapis. Protein dengan berat molekul besar juga tidak ditemui pada fraksi ini, seperti yang sudah dibahas sebelumnya bahwa hidrolisat kasein susu kambing yang dihidrolisis oleh enzim papain hanya menunjukkan pita protein dengan berat molekul kecil (Gambar 1).

Hidrolisat P0 fraksi 10-30 kDa, dan hidrolisat P2 fraksi $>30 \mathrm{kDa}$ tidak diperoleh pita yang jelas. Ketebalan pita menunjukkan konsentrasi protein, semakin tebal pita maka konsentrasi protein akan semakin tinggi (Sintae et al., 2015). Proses fraksinasi menyebabkan peptida-peptida dengan berat molekul kecil terkonsentrasi pada fraksi $<10 \mathrm{kDa}$, sehingga ditemui pita protein yang tebal pada fraksi $<10 \mathrm{kDa}$ (baik hidrolisat P0 dan P2) dibandingkan fraksi-fraksi lainnya dan juga dibandingkan sebelum fraksinasi.

\section{Aktivitas antioksidan setelah proses fraksinasi}

Peptida dengan ukuran di atas $30 \mathrm{kDa}$ pada kedua hidrolisat tidak memiliki aktivitas antioksidan. Aktivitas antioksidan tertinggi hidrolisat P0 ditemukan pada fraksi $<10 \mathrm{kDa}$, sedangkan pada hidrolisat P2, aktivitas antioksidan tertinggi terdapat pada fraksi 10-30 kDa (Gambar 4). Hidrolisat P0 dan P2 dengan berat molekul diatas $30 \mathrm{kDa}$ tidak memiliki aktivitas antioksidan sedangkan hidrolisat P0 dan P2 dengan berat molekul dibawah $30 \mathrm{kDa}$ memiliki aktivitas antioksidan. Fraksi dengan berat molekul di bawah $30 \mathrm{kDa}$ pada kedua hidrolisat diduga mengandung asam amino yang mampu mendonorkan hidrogen maupun melakukan transfer elektron seperti asam amino hidrofobik, aromatik ataupun mengandung gugus sulfur (Zou et al., 2016).

Hidrolisat P0 dengan berat molekul $<10 \mathrm{kDa}$ memiliki aktivitas antioksidan sebesar $67,8 \%$. Nilai ini meningkat dari aktivitas antioksidan hidrolisat P0 sebelum difraksinasi yaitu sebesar $63,4 \%$. Hal yang sama juga terjadi pada hidrolisat P2 dengan berat molekul 10-30 kDa yang memiliki aktivitas antioksidan sebesar $73,8 \%$ dan hidrolisat $\mathrm{P} 2$ dengan berat molekul $<10 \mathrm{kDa}$ dengan aktivitas antioksidan $66 \%$, keduanya lebih tinggi dari aktivitas hidrolisat P2 sebelum difraksinasi yaitu sebesar $63,3 \%$.

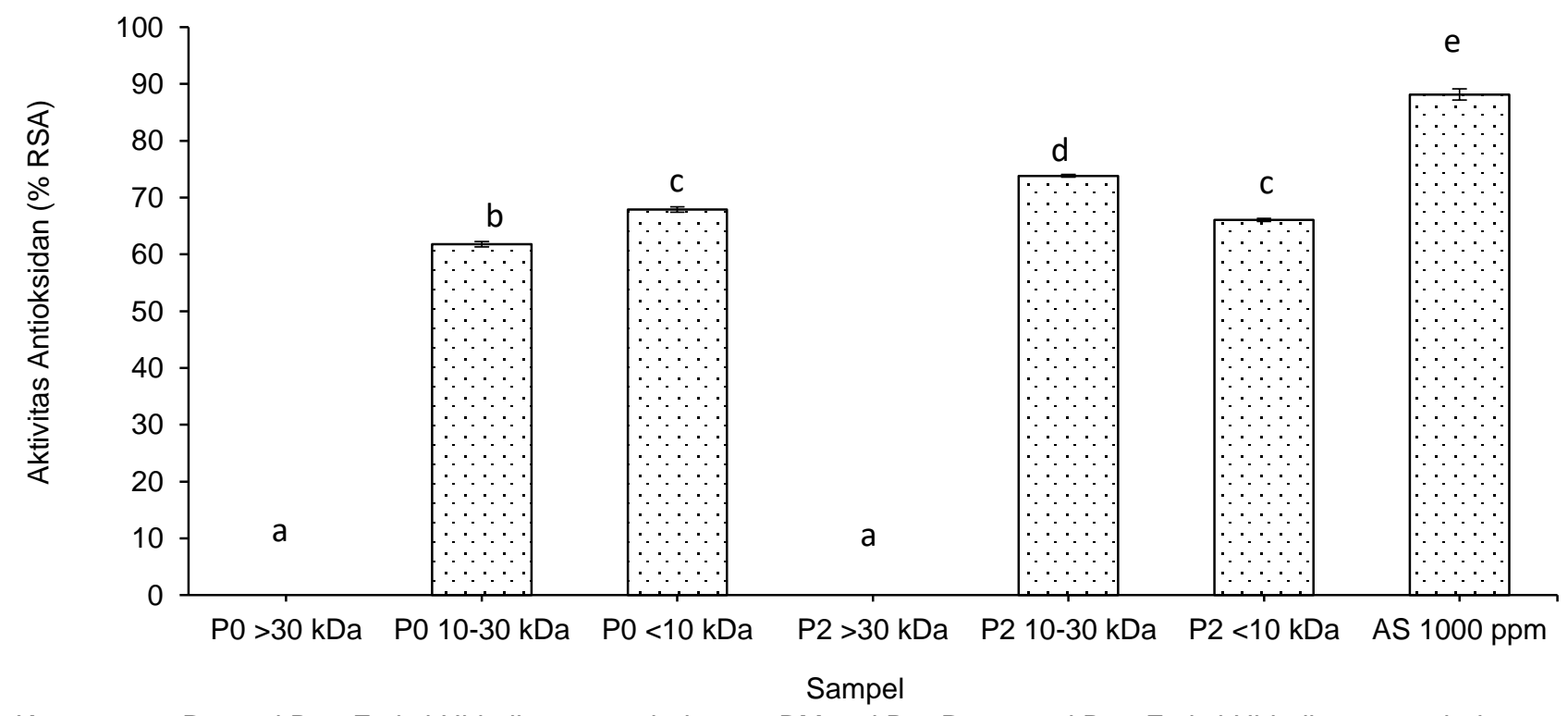

Keterangan: $\mathrm{P} 0>30 \mathrm{kDa}=$ Fraksi Hidrolisat 0 menit dengan $\mathrm{BM}>30 \mathrm{kDa} ; \mathrm{P0}$ 10-30 kDa= Fraksi Hidrolisat 0 menit dengan BM 10-30kDa; $\mathrm{P} 0<10 \mathrm{kDa}=$ Fraksi Hidrolisat 0 menit dengan $\mathrm{BM}<10 \mathrm{kDa}$ ); $\mathrm{P} 2>30 \mathrm{kDa}=\mathrm{Fraksi}$ Hidrolisat 2 menit dengan $\mathrm{BM}>30 \mathrm{kDa}$; P2 10-30 kDa= Fraksi Hidrolisat 2 menit dengan BM 10-30kDa, P2<10 kDa= Fraksi Hidrolisat 2 menit dengan $\mathrm{BM}<10 \mathrm{kDa}$; $\mathrm{AS} 1.000 \mathrm{ppm}=$ kontrol positif asam askorbat

Gambar 4. Aktivitas antioksidan (\% RSA) hidrolisat P0 dan P2 setelah proses fraksinasi 
Proses penyaringan dapat memekatkan konsentrasi protein, seperti yang sudah dibahas sebelumnya sehingga aktivitas antioksidan yang dihasilkan pun meningkat. Proses penyaringan dapat menyebabkan protein besar yang tidak memiliki aktivitas antioksidan tertahan pada membran sehingga diperoleh peptida yang lebih murni dengan aktivitas antioksidan lebih tinggi. Hal ini menyebabkan terjadinya kenaikan aktivitas antioksidan sesudah proses penyaringan (Kusumaningtyas et al., 2015b).

Hidrolisat susu kambing menggunakan enzim bromelin (suhu $50^{\circ} \mathrm{C}$ selama 60 menit) diketahui memiliki aktivitas antioksidan dengan aktivitas pada fraksi $<10 \mathrm{kDa}(14 \%)$ lebih besar daripada fraksi $>10$ kDa (4\%) (Kusumaningtyas et al., 2015b). Nilai yang lebih rendah tersebut ini mungkin disebabkan pada susu kambing utuh masih banyak mengandung komponen lain seperti lemak dan pengotor lain yang dapat mengurangi aktivitas antioksidan. Rekomendasi untuk penelitian lebih lanjut dapat dilakukan sekuensing asam amino dari fraksi $<10 \mathrm{kDa}$ hidrolisat P0 dan fraksi 10-30 kDa hidrolisat P2 dengan aktivitas antioksidan tertinggi untuk mengetahui susunan dan komposisi asam amino yang memberikan aktivitas antioksidan.

\section{KESIMPULAN}

Peptida bioaktif antioksidan berhasil diperoleh dari kasein dan papain dengan waktu hidrolisis 0,1 , 2, dan 3 menit. Kasein susu kambing menunjukkan 6 pita protein dengan berat molekul 7-33 kDa, sedangkan hidrolisat yang diperoleh memiliki berat molekul sekitar 8 dan $5 \mathrm{kDa}$. Hidrolisat P0 dan P2 mempunyai aktivitas antioksidan yang tinggi, dengan fraksi yang memiliki aktivitas antioksidan tertinggi adalah fraksi $<10 \mathrm{kDa}$ pada hidrolisat P0 dan 10-30 kDa pada hidrolisat P2. Dapat disimpulkan bahwa peptida dengan aktivitas antioksidan yang berasal dari kasein susu Kambing peranakan etawa merupakan peptida dengan berat molekul maksimum adalah $<30 \mathrm{kDa}$.

\section{UCAPAN TERIMA KASIH}

Penulis menyampaikan ucapan terima kasih kepada LPPM Unika Atma Jaya yang telah mendanai penelitian ini melalui dana hibah Penelitian Fakultas.

\section{DAFTAR PUSTAKA}

Bezerra VS. 2013. Biotechnological richness of the northeastern semi-arid region: Antioxidant activity of casein hydrolysates from Moxoto goat milk (Capra hircus Linnaeus) obtained by papain action. Food Sci Technol 33: 513-520. DOI: 10.1590/S0101-20612013005000074.

Chalabi M, Khademi F, Yarani R, Mostafaie A. 2014. Proteolytic activities of kiwifruit actinidin (Actinidia deliciosa cv. Hayward) on different fibrous and globular proteins: A comparative study of actinidin with papain. Appl Biochem Biotechnol 172: 4025-4037. DOI: $10.1007 / \mathrm{s} 12010-014-08$ 12-7.

Costa WKA, Souza EL, Beltrao-Filho EM, Vasconcelos GKV, Santi-Gadelha T, Gadelha CAA, Franco OL, Queiroga RCRE, Magnani M. 2014. Comparative protein composition analysis of goat milk produced by the Alpine and Saanen breeds in Northeastern Brazil and related antibacterial activities. PLos One 9: e93361. DOI: 10.1371/journal.pone.0093361.

He F. 2011. Bradford Protein Assay. Bio-101: e45. DOI: 10.21769/BioProtoc. 45 .

Herlina N, Mustopa AZ, Surachma RS, Triratna L, Kartina G, Alfisyahrin WN. 2019. Aktivitas antibakteri dan antioksidan peptida susu kambing hasil hidrolisis dengan protease Lactobacillus plantarum S31. J Biol Indonesia 15: 23-31. DOI: 10.47349/jbi/15012019/23.

Janson JC. 2012. Protein Purification: Principles, High Resolution Method And Application. 4-21. John Willey and Sons, London.

Jung TH, Hwang HJ, Yun SS, Lee WJ, Kim JW, Ahn JY, Jeon WM, Han KS. 2017. Hypoallergenic and physicochemical properties of the a2 $\beta$-casein fraction of goat milk. Korean J Food Sci An 37: 940-947. DOI: 10.5851/kosfa.2017.37.6. 940.

Kusumadjaja AP, Dewi RP. 2010. Determination of optimum condition of papain enzyme from papaya var java (Carica papaya). Indonesian J Chem 5: 147-151. DOI: 10.22146/ijc.21822.

Kusumaningtyas $E$, Widiastuti $R$, Kusumangingrum HD, Suhartono MT. 2015a. Antimicrobial and antioxidative activities of peptides from goat milk hydrolyzed with various protease. J IImu Ternak dan Veteriner 20: 175-183. DOI: 10.143 34/jitv.v20i3.1184.

Kusumaningtyas $\mathrm{E}$, Widiastuti R, Kusumangingrum HD, Suhartono MT. 2015b. Aktivitas antibakteri dan antioksidan hirolisat hasil hidrolisis protein susu kambing dengan ekstrak kasar bromelin. J Teknol Industri Pangan 26: 179-188. DOI: 10. 6066/jtip.2015.26.2.179.

Lestari D, Soesilo VV. 2017. Aktivitas antibakteri peptida kasein susu kambing hidrolisis oleh papain terhadap Pseudomonas aeruginosa. J IImu 
Pangan Hasil Pertanian 1: 81-92. DOI: 10.2687 7/jiphp.v1i2.1914.

Matsuura Y, Takehira M, Joti Y, Ogasahara K, Tanaka M, Ono N, Kunishima N, Yutani K. 2015. Thermodynamics of protein denaturation at temperatures over $100^{\circ} \mathrm{C}$ : CutA1 mutant proteins substituted with hydrophobic and charged residues. Scientific Reports 5: 15545. DOI: 10. 1038/srep15545.

Mohanty DP, Mohapatra S, Misra S, Sahu PS. 2016. Milk derived bioactive peptides and their impact on human health-a review. Saudi J Biol Sci 23: 577-583. DOI: 10.1016/j.sjbs.2015.06.005.

Padaga MC, Aulanni'am. 2017. Susu sebagai nutrasetika untuk penyakit gangguan metabolik. 2635. Universitas Brawijaya Press, Malang.

Park YW. 1994. Hypo-allergenic and therapeutic significance of goat milk. Small Ruminant Res 14: 151-159. DOI: 10.1016/0921-4488(94)9010 5-8.

Purwanto MGM. 2014. Perbandingan analisa kadar protein terlarut dengan berbagai metode spektroskopi UV-visible. Tekno Sains 7: 1-71.

Ratya N, Taufik E, Arief II. 2017. Karakteristik kimia, fisik dan mikrobiologis susu kambing peranakan etawa di bogor. J Ilmu Produksi Teknol Hasil Peternakan 5: 1-4. DOI: 10.29244/jipthp.5.1.14.

Rawlings ND, Salvesen G. 2013. Handbook of Proteolytic Enzymes. Chapter 419 Papain. 1858-1861. Academic Press is an imprint of Elsevier, London.
Selvaggi M, Laudadio V, Dario C, Tufarelli V. 2014. Major proteins in goat milk: an updated overview on genetic variability. Mol Biol Rep 41: 1035-1048. DOI: 10.1007/s11033-013-2949-9.

Singh P, Benjakul S, Masqsood S, Kishimura H. 2011. Isolation and characterization of collagen extracted from skin of stripped catfish (Pangasianodon hypopthalamus). Food Chem 124: 97105. DOI: 10.1016/j.foodchem.2010.05.111.

Sintae RN, Suwiti NK, Suardana IW. 2015. Karakteristik protein dan asam amino daging sapi bali dan wagyu pada penyimpanan suhu dingin $4^{\circ} \mathrm{C}$. Buletin Veteriner Udayana 7: 146-156.

Syukur R, Alam G, Mufidah, Rahim A, Tayeb R. 2011. Aktivitas antiradical bebas beberapa ekstrak tanaman familia Fabaceae. JST Kesehatan 1: 61-67.

Utami P, Lestari S, Lestari SD. 2016. Pengaruh metode pemasakan terhadap komposisi kimia dan asam amino ikan seluang (Rasbora argyrotaenia). Fish TecH-J Teknol Hasil Perikanan 5: 73-84.

Wang J, Su Y, Jia F, Jin H. 2013. Characterization of casein hydrolysates derived from enzymatic hydrolysis. Chem Cent J 7: 1-8. DOI: 10.1186/ 1752-153X-7-62.

Yangilar F. 2013. As a potentially functional food: Goat milk and products. J Food Nutr Res 1: 6881.

Zou TB, He TP, Li HB, Tang HW, Xia EQ. 2016. The structure-activity relationship of the antioxidant peptides from natural proteins. Molecules 21: 1-14. DOI: 10.3390/molecules21010072. 